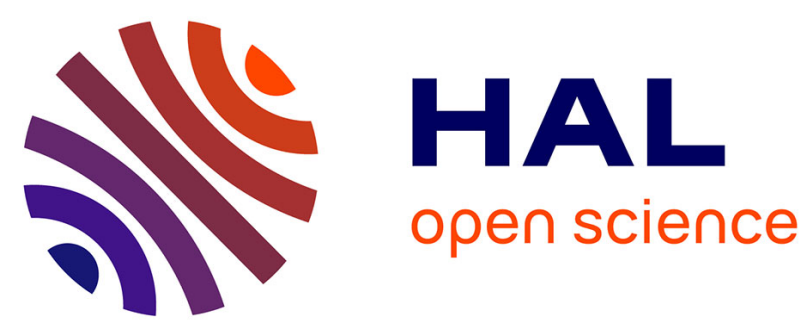

\title{
Vegetation maps based on remote sensing are informative predictors of habitat selection of grassland birds across a wetness gradient
}

Aurélien G. Besnard, Aurélie Davranche, Sébastien Maugenest, Jan-Bernard Bouzillé, Alain Vian, Jean Secondi

\section{To cite this version:}

Aurélien G. Besnard, Aurélie Davranche, Sébastien Maugenest, Jan-Bernard Bouzillé, Alain Vian, et al.. Vegetation maps based on remote sensing are informative predictors of habitat selection of grassland birds across a wetness gradient. Ecological Indicators, 2015, 58, pp.47-54. 10.1016/j.ecolind.2015.05.033 . hal-01161554

HAL Id: hal-01161554

https://hal-univ-rennes1.archives-ouvertes.fr/hal-01161554

Submitted on 10 Jun 2015

HAL is a multi-disciplinary open access archive for the deposit and dissemination of scientific research documents, whether they are published or not. The documents may come from teaching and research institutions in France or abroad, or from public or private research centers.
L'archive ouverte pluridisciplinaire HAL, est destinée au dépôt et à la diffusion de documents scientifiques de niveau recherche, publiés ou non, émanant des établissements d'enseignement et de recherche français ou étrangers, des laboratoires publics ou privés. 


\section{Vegetation maps based on remote sensing are informative}

\section{2 predictors of habitat selection of grassland birds across a wetness}

3 gradient

$4 \quad$ Besnard, A.G. ${ }^{1 *}$, Davranche A. ${ }^{2}$, Maugenest S. ${ }^{1}$, Bouzillé J.B. ${ }^{3}$, Vian A. ${ }^{4}$, Secondi, J. ${ }^{1}$

$5 \quad$ Running title: Vegetation mapping highlights habitat selection

6

E-mail addresses:

7

aurelien.besnard@univ-angers.fr

$8 \quad$ aurelie.davranche@univ-angers.fr

$9 \quad$ sebastien.maugenest@univ-angers.fr

10 jan-bernard.bouzille@univ-rennes1.fr

11 alain.vian@univ-angers.fr

jean.secondi@univ-angers.fr

* corresponding author

${ }^{1}$ LUNAM University, University of Angers, GECCO (Group Ecology and Conservation of Vertebrates), 49045 Angers, France; Telephone number: 33241735030

${ }^{2}$ LUNAM University, University of Angers, LETG - LEESA, 2 Boulevard Lavoisier, 

France

23 Whinchat, Corncrake, Yellow Wagtail, Corn Bunting, Reed Bunting. 


\section{Abstract}

Vegetation is a major environmental factor influencing habitat selection in bird species. High resolution mapping of vegetation cover is essential to model the distribution of populations and improve the management of breeding habitats. However, the task is challenging for grassland birds because microhabitat variations relevant at the territory scale cannot be measured continuously over large areas to delineate areas of higher suitability. Remote sensing may help to circumvent this problem. We addressed this issue by using SPOT 5 imagery and phytosociological data. We mapped grassland vegetation in a floodplain using two methods. We (i) mapped the continuous Ellenberg index of moisture and (ii) identified 5 vegetation classes distributed across the wetness gradient. These two methods produced consistent output maps, but they also provided complementary results. Ellenberg index is a valuable proxy for soil moisture while the class approach provided more information about vegetation structure, and possibly trophic resources. In spite of the apparent uniformity of meadows, our data show that birds do not settle randomly along the moisture and vegetation gradients. Overall birds tend to avoid the driest vegetation classes, i.e. the highest grounds. Thus, vegetation maps based on remote sensing could be valuable tools to study habitat selection and niche partition in grassland bird communities. It is also a valuable tool for conservation and habitat management.

\section{Highlights}

- We mapped grassland vegetation in a floodplain using two methods

- The Ellenberg index proves to be a valuable proxy for soil moisture

- Vegetation classes provided more information about vegetation structure 
- Grassland birds do not settle randomly along the vegetation gradient

- Vegetation maps based on remote sensing are useful tools to study habitat selection 


\section{Introduction}

Delimiting zones of protection is a major issue of conservation programs (McNeely, 1994;

Moilanen et al., 2009). In order to identify core protection areas and optimize management, policy makers need robust background information like precise ecological requirements for target species.

Grasslands present an interesting case in that respect because they often appear to human eyes as

large expanses of uniform vegetation. For this reason, designing efficient protection areas in grasslands may seem challenging but this objective needs to be met. Due to anthropogenic changes, grassland birds are threatened in several part of the World (Azpiroz et al., 2012; Brennan and Kuvlesky, 2005; Tryjanowski et al., 2011; Tucker et al., 1994). Agri-Environmental Schemes (AES) were implemented in the 1990's within the European Union to subsidize grassland management compatible with breeding but many species have continued to decline (Kleijn et al., 2006). Precise knowledge of habitat selection for target species is therefore crucial to design new and more ecologically oriented AES measures in areas where conservation objectives partly failed.

Although their breeding habitat may seem homogeneous, grassland species do not settle at random in meadows. Spatial variations in density are frequently observed. For instance, many species are area-sensitive and avoid small fragments of habitats (Besnard and Secondi, 2014; Davis and Brittingham, 2004; Helzer and Jelinski, 1999). Even in larger patches, they tend to avoid landscape features like hedges because of higher predation risk (Morris and Gilroy, 2008). Vegetation itself offers various level of suitability for nesting. Vegetation structure is a major feature that influences the settlement of grassland birds (Fisher and Davis, 2010; Jacobs et al., 2012). Plant community largely determines arthropod assemblages (Schaffers et al., 2008) and therefore the 
prefer areas with higher densities of flowers during the breeding season (Fischer et al., 2012). This preference may reflect higher prey availability to feed the young (Oppermann, 1990). Vegetation cover also determines predation risk (Ejsmond, 2008), particularly the ability of birds to hide their nests under the canopy (Whittingam and Evans, 2004). Therefore, grassland birds tend to select nest site with taller swards and denser vegetation (Davis, 2005). In addition, some species need herbaceous perches for foraging and territorial defence (Fischer et al., 2012; Oppermann, 1990).

Soil moisture is a major factor of grassland ecology (Price, 2002; Suzuki et al., 2006). It is considered as the main driver of vegetation patterns in most regions (Moeslund et al., 2013),. Flood is a recurrent phenomenon that generates a wetness gradient and structures vegetation communities (Martinez and Letoan, 2007). However, wetness is also influenced by local environmental conditions like altitude, microtopography, or soil. Fortunately, vegetation has the property to integrate all the components of wetness (Goward et al., 1991). Mapping vegetation in relation to its affinity for moisture is expected to provide informative predictors to analyse habitat selection in grassland birds and improve the management of these habitats. Satellite remote sensing techniques are promising tools in this regard. They provide vegetation data with a spatial resolution high enough to analyse habitat selection in birds across ecological gradients. Furthermore, satellite images often cover geographical ranges large enough to delineate areas with different levels of conservation priority (Guo, 2004; Poulin et al., 2010).

We assessed two methodological approaches to describe the variation of grassland vegetation across the wetness gradient in floodplains. We used the Ellenberg moisture index that attributes a value to each vegetal species, corresponding to its affinity for soil moisture (Ellenberg et al., 1992). We computed a continuous wetness gradient based on the mean Ellenberg index of the local vegetation community to map the wetness gradient across a floodplain. In addition, we tested a 
discrete method to map vegetation classes as defined by the phytosociological approach (Tichý, 2002). A vegetation class is "a system of vegetal organisms with a floristic composition that is statistically repetitive" (Biondi, 2011). Each class may offer a specific level of suitability for birds depending on its physical properties and the various resources it provides. In grasslands, these vegetation classes may therefore be an informative proxy to describe habitat requirements of bird species. This approach may be easier to apply for managers since habitats are determined and their conservation prioritized according to vegetation associations, for instance in the European Union (Davies et al., 2004). Finally, AES are implemented in our study area to protect grassland and birds. We tested if AES types were related to vegetation community, i.e. the hydrological functioning of the floodplain, and if the spatial distribution of AES matched habitat selection of birds as described by vegetation. 


\section{Methods}

The study area covers the floodplains of the Loire River and its main tributaries around Angers city in France $(47.48,-0.56)$ (Fig. 1). Hydrological flow is relatively undisturbed by anthropogenic developments in contrast to other floodplains of similar size in Western Europe (Hesselink et al., 2003). Due to frequent floods, extensively managed grasslands still represent the main land cover type. Agricultural practices consist in mowing meadows once a year in June-July and in allowing low intensity grazing by cattle during vegetation regrowth. Considering the shallow slope of the ground, plant community mainly depends on soil wetness and submersibility. Owing to their management, these grasslands still host several patrimonial bird species, like the Corncrake (Crex crex), known to be highly sensitive to intensive agriculture (Green et al., 1997a). Many grassland bird species collapsed in the second part of $20^{\text {th }}$ century, mainly due to the intensification of practices (more efficient machinery, fertilisation, advanced mowing schedule). Agri-environmental schemes (AES) that were implemented locally mainly consisted in delaying hay mowing. The proportion of grassland under AES is quite high in the study area (45\% in 2011). Several levels of AES measures are present in the study area, differing mainly by the earliest mowing date. For clarity, we aggregated parcels in two sets: those mown in June ( 3540 ha) and those mown in July (1 571 ha). Mowing before July causes high mortality in broods (Broyer, 2007; Green et al., 1997b). Therefore, we considered that meadows mown in June were not suitable for the sustainable breeding of grassland birds. 
Figure 1: Map of grassland distribution in the study area. The inset shows the location in Europe.

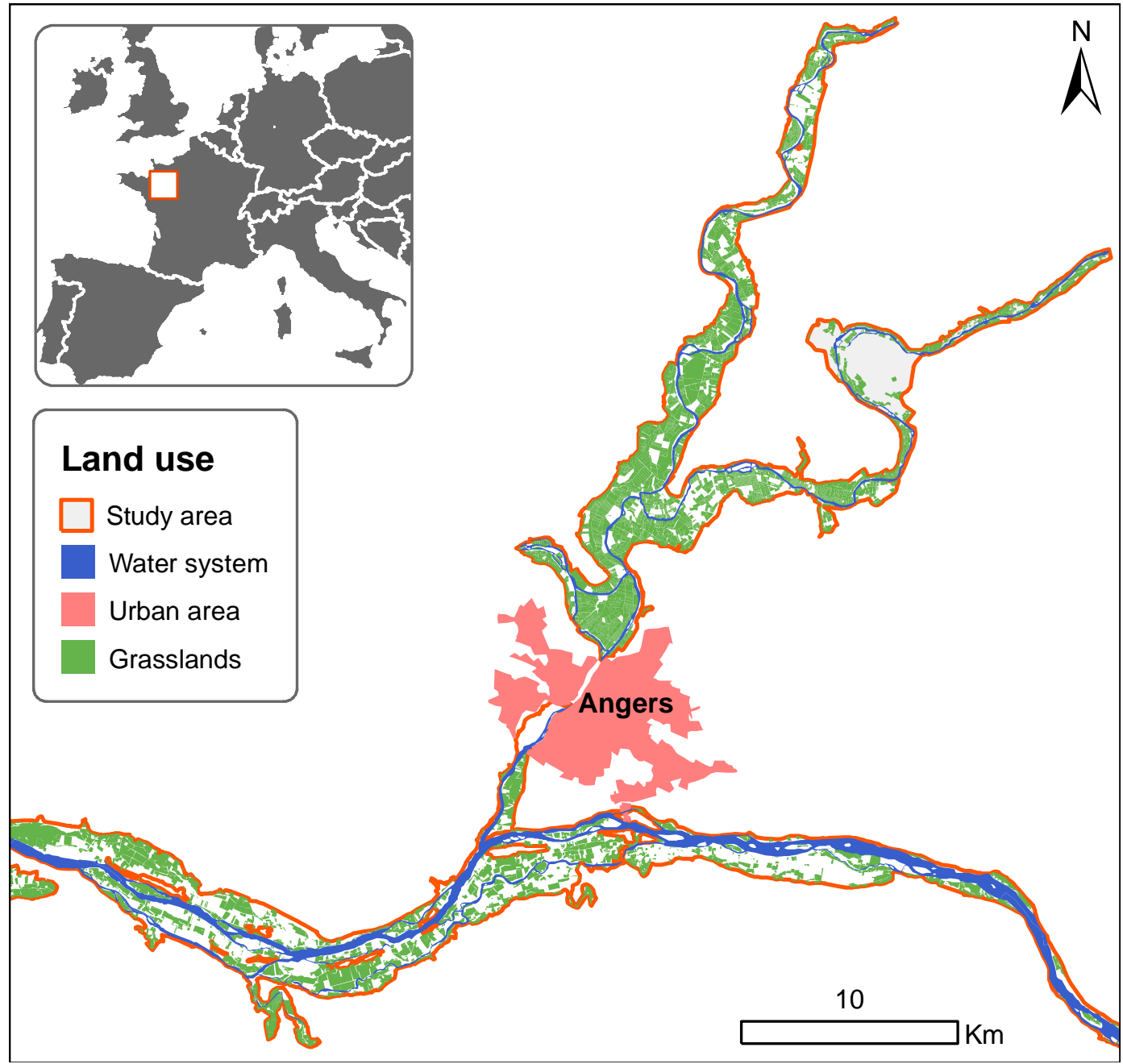

We conducted phytosociological relevés on 107 plots to describe vegetation community across the whole study area. Survey was carried out from May $16^{\text {th }}$ to June $10^{\text {th }} 2011$ to ensure the reliable identification of plant species. A plot was defined by the standard $16 \mathrm{~m}^{2}$ quadrat method (Chytrý and Otýpková, 2003). Quadrats were selected in a larger zone of homogeneous vegetation to limit the 
process. We sampled as many contrasting situations along the flooding gradient as possible basing on our knowledge of the study area. Sampling plots were positioned using a Differential Global Positioning System (DGPS), through a Trimble ${ }^{\odot}$ Juno $^{\odot}$ SB. The estimated georeferencing error after post-processing was $6 \mathrm{~m}$ maximum. However it was lower than $4 \mathrm{~m}$ for $93 \%$ of plots. All species in the quadrat were identified using either a local specific flora (Corillon, 1981) or a vegetative flora (Eggenberg and Möhl, 2013) when necessary. Area covered by each species was evaluated using a Braun-Blanquet coefficient (Braun-Blanquet, 1964). We then classified relevés with JUICE software (Tichý, 2002), using the TWINSPAN method (Hill, 1979), including standard relevés from a previous study conducted in the same area (Foucault, 1984) as referentials for the classification. This method classifies relevés according to their similarity in order to identify phytosociological taxa. We identified five taxa along the wetness gradient in the area: 1 . Phalaridion arundinaceae, Kopecky 1961; 2. Gratiolo officinalis-Oenanthetum fistulosae inferior, De Foucault, 1984 nom. Ined; 3. Gratiolo officinalis-Oenanthetum fistulosae superior, De Foucault 1984 nom. Ined; 4. Senecio aquaticiOenanthetum mediae, Bournerias et al. 1978; 5. Arrhenaterion elatioris, Hoch, 1926. The wettest and the driest have been considered at the alliance level owing to the diversity of associations encountered in the field for these two taxa. The three intermediate classes $(2-4)$ have been specified to the association level because their observed compositions matched the original descriptions. However, the Gratiolo officinalis-Oenanthetum fistulosae was split in two due to the wide area it covered and named in accordance with the type relevés described by De Foucault (1984). We tested the significance of those partitions with a non-parametric multivariate analysis of variance (Anderson, 2001) using adonis from the vegan R-package (Oksanen, 2013). 
indexes determine the affinity of each species for environmental parameters like light, temperature,

161

162 or nitrogen in soil (Ellenberg et al., 1992). We used here moisture affinity scores which are available for each species (Hill et al., 1999). A value of 1 is given to a specialist of the driest habitats and a value of 12 for a specialist of the wettest habitats. The indicator value of Ellenberg scores has been evaluated by a field study that concluded that they were very good descriptors of the local environment (Schaffers and Sýkora, 2000). For each plot, we averaged Ellenberg values of all species, regardless of their cover, to obtain a single value. We considered this value as a proxy of soil wetness at the plot scale. We computed average Ellenberg scores weighted by species cover and unweighted. The unweighted method gave more realistic outputs. This is because cover depends mainly on the sociability, for example the cover of grasses species is often high whereas sparse species like Fritillaria meleagris can have a more informative value In addition, weighted average penalize rare species that often display narrow niches and are informative indicators.

\subsection{Mapping}

A SPOT $5^{\odot}$ satellite image $2.5 \mathrm{~m}$ colour, correction level $2 \mathrm{~B}$ (allocation accuracy less than $10 \mathrm{~m}$ ), was acquired on May $5^{\text {th }} 2011$. These scenes are provided with three bands: B1 (green: 0.50 to 0.59 $\mu \mathrm{m}$ ), B2 (red: 0.61 to $0.68 \mu \mathrm{m}$ ), B3 (near-infrared NIR: 0.79 to $0.89 \mu \mathrm{m}$ ). A mask of all the meadows within the floodplains was applied on this scene (60 km long $\times 60 \mathrm{~km}$ wide) to delineate the whole study area using in ARCGIS version 10 (Environmental Systems Research Institute, Meudon France). All analyses were conducted with this mask. Conditions of image acquisition were optimal with a low incidence angle $\left(4.77^{\circ}\right)$ and cloud cover less than $10 \%$. Spring 2011 was relatively dry so all the study area was emerged but a small 41-ha zone that is kept flooded to provide spawning sites for fishes. A 
182

183

184

185

186

187

Table 1 Multispectral indices used in this study.

ID index

Multispectral index

Differential Vegetation Index (DVI)

Index of free water (IFW)

2

3

4

5

6

7

8

9

10

11

12

13

14

15

16

17

18
Normalized Difference Vegetation Index (NDVI)

Normalized difference water index (NDWI)

Optimized Soil Adjusted Vegetation Index (OSAVI)

B3

B2

$\mathrm{B} 2 / \mathrm{B} 1$

Soil Adjusted Vegetation Index (SAVI)

Brightness index (BI)

Simple ratio (SR)

B1

B1-B2

(B1-B2)/(B1+B2)

$\mathrm{B} 12 / \mathrm{B} 2$

Vegetation indice (VI)

Water index (WI)

Water impoundment index (WII)

\section{References}

Richardson \& Everitt, 1992

Adell \& Puech, 2003

Rouse et al., 1973

Mc Feeters, 1996

Rondeaux et al., 1996

Spot image

Spot image

This study

Huete, 1988

Kauth and Thomas, 1976

Pearson \& Miller, 1972

Spot image

This study

This study

This study

Lillesand \& Kiefer, 1987

Davranche et al, 2013

Caillaud et al., 1987 

partitioning (Breiman et al., 1984). It was performed for each class using a binary coding: presence or

193 absence. We also tested a multiple-class classification, where we attempted to identify all classes in the same analysis, but this method gave poor results. The Rpart package (Recursive PARTitioning, Therneau and Atkinson, 1997) in the R software version 2.15.2 software (Rdevelopment core team, 2012) was used. This method is based on the cost complexity parameter (cp) for pruning. As described in Davranche et al. (2010) for unbalanced samples, we used the cross-validation procedure called CV-1SE (Esposito et al., 1999) for pruning with 10 subsets and iterative runs of the algorithm (Breiman et al., 1984) to select the $\mathrm{cp}$ and the prior parameter. Cross-validation is well suited to small samples (Breiman et al., 1984)., so it can be recommended when no additional independent sample is available.

The distribution of wetness Ellenberg index was checked for normality. We used linear models to test whether index values obtained from field relevés could be predicted from remote sensing variables). Models with all combinations of predictors were computed with the 'Im' function from the R-package 'stats'. Model selection was carried out using the 'dredge' function of the R-package 'MuMIn' (Barton, 2013). The best model was selected according to the lowest AICc value (Burnham and Anderson, 2002) (Appendix 1 in Supplementary material). As advised by Symonds and Moussali (2011), we assessed the goodness-of-fit of this best AICc model, by calculating the coefficient of determination $\left(\mathrm{R}^{2}\right)$ and the normalized root-mean-square error (NRMSE) between the predicted and observed values. 
The study area host several breeding grassland species, some of which have been declining for several decades in Western Europe (Tucker et al., 1994). We sampled the 4 dominant passerine species in this small avian community: the Whinchat Saxicola rubetra, the Yellow Wagtail Motacilla flava, the Corn Bunting Emberiza calandra and the Reed Bunting Emberiza schoeniclus (Noël, 2003).

We scanned every hay meadows of the study area during the 2011 breeding season to locate birds. We used binoculars (10x42) and a spotting scope (20x-60x,66mm) to detect and identify species. Fieldwork was performed from April 13th to June 17th 2011 in good weather conditions (no precipitation and low wind) to optimize bird detection and avoid the recording of migrating birds. The time of day was not considered to maximize the area surveyed during the breeding season. However, the detection rate of these species remains relatively high throughout the day, even in the late afternoon when males rest on the top of vegetation. All occurrences were located on a map (IGNC 1:25 000), and reported on a GIS software (ArcGISC 10) by the same observer. We also used the Corncrake database from LPO France (French official BirdLife partner). These data were collected in 2011 by volunteer ornithologists who located singing males at night. Like for passerines, Corncrake data were compiled in a GIS dataset. Overall, we observed 451 Whinchats, 151 Yellow Wagtails, 114 Corn Buntings, 174 Reed Buntings, and we used 479 occurrences of Corncrake across the study area.

\subsection{Statistical analyses}

In order to compare Ellenberg index values on bird locations with background values, we defined 1501 background plots distributed across a 250m-grid. We created a buffer zone of 100m around each bird location and background plot. We extracted the average wetness index for all pixels included in the buffer area. For each bird species, we then compared mean wetness values on location buffers and background plots using a Wilcoxon test based on bootstrap (1000 iterations of 
background values with $n \geq 114$ corresponding to the sample size of each species) with the $R$ software (version 3.0.2).

Similarly, we extracted the mean area covered by each vegetation class within $100 \mathrm{~m}$-buffers around each bird location. Knowing that each class was calculated independently, a pixel can be assigned to several classes. We compared values for each class to the area covered by the same class in the whole study area, and tested the differences between the two variables using a Wilcoxon test. We measured selection or avoidance by birds for each class by calculating the difference in the distributions of vegetation classes between bird and random location using background plots described above ( $n=1501)$.

In order to compare the two methods (Ellenberg wetness index and vegetation classes), we used 44 transects of $500 \mathrm{~m}$ long surrounded with a $100 \mathrm{~m}$-buffer (i.e. $13.1 \mathrm{ha}$ ). These transects were distributed across the floodplain in open meadows selected for their suitable landscape for grassland birds. These were previously used with success to investigate the interest of the topographic wetness index as a predictor of grassland bird distribution (Besnard et al., 2013). For the two vegetation maps, we extracted mean values (Ellenberg index and vegetation class) on these transects and we fitted a linear model between these two datasets. We also used Chi-squared tests to test whether vegetation classes and bird distributions were randomly distributed across mowing dates. All tests were carried out using R software (version 3.0.2). Finally, we could determine the pattern of flooding susceptibility in 35 plots spread across the study area during a spring flood (April-June) in 2013. We sampled these plots twice a week before, during and after the flood, and derived a flood index which corresponds to the number of times the plots were flooded. To determine whether Ellenberg index was related to submersibility, we fitted a linear model between flood index and mean Ellenberg index on plots. 


\section{Results}

Using remote sensing method we could map the wetness gradient based on Ellenberg moisture index across the hay meadows of the study area (Fig. 2; Best model : $d f=7$, LogLik=110.97, AICc= 237.08, weight $=0,00048, R^{2}=0.41$, NRMSE $=19 \% ; Y=114,10+0,19 * \mathrm{DVI}+49,73 * \mathrm{NDWI}+1,65 * \mathrm{~B} 2+$ 164,96*B2/B1 + 0,65*B1²/B2 (More details on model selection in Table S2 in Supplementary material). The map was consistent with the observed flood susceptibility pattern ( $F_{1,33}=25.09$; $p<0.001$, adjusted $R^{2}=0.43$ ) (Fig. 3a). The resulting trees for the classification of vegetation classes provided the following error rates $C_{1}: 9 \%, C_{2}: 14 \%, C_{3}: 16 \%, C_{4}: 16 \%, C_{5}: 10 \%$. Plant species composition was significantly different between classes as defined by Twinspan $\left(F_{1,106}=5.62\right.$; $p=0.001)$. Using transect data, we found that average vegetation class was strongly correlated with Ellenberg moisture index $\left(F_{1,42}=116.1 ; p<0.001\right.$; adjusted $\left.R^{2}=0.73\right)$ (Fig. $\left.3 b\right)$ confirming the value of these two methods to map wetness gradients. We noticed that the cover of class 5 is probably overestimated on a part of the wettest area. This area was submerged by water several weeks before the image capture and vegetation reflectance was modified by alluvium deposits. It was classified as belonging both to the wettest classes (1-3) and class 5 but field data confirm that this latter class was not observed there. This classification error causes an underestimation of avoidance of class 5 by birds because this area exhibit high bird densities. Nevertheless, we detected an avoidance of this class for 4 species. Thus, this limit does not alter the conclusion of this study.

All bird species except the Corn bunting settled in meadows with Ellenberg values higher than random locations in the study area (Bootstrap based on Wilcoxon test; $p<0.001$ ) (Fig. 4 and Table 2). Yet, this species also tended to select plots with high Ellenberg values ( $p=0.10 \pm 0.16)$. Generally, birds selected wetter hay meadows than available in the study area (Fig. 4 and Table 2). The analysis 
of vegetation classes provided supplementary information (Fig. 5). Except for the Corn Bunting, the three wettest vegetation classes represented a larger proportion of the buffers around bird locations than available (Table 3). For all species but the Whinchat, the driest vegetal class (5) represented a smaller proportion of the buffer area around bird locations than expected by chance. For all species, vegetation class 3 was more represented around bird location than available. Results were more contrasting for vegetation class 4 . It was more represented around bird locations for the Corn Bunting and the Whinchat, whereas it was less represented for the Reed Bunting and the Corncrake. More globally, the pattern of habitat selection for vegetation classes was different between species

The proportion of area covered by each vegetation class differed between AES contract types $\left(\mathrm{Chi}^{2}=350.75, \mathrm{df}=4, \mathrm{p}<0.001\right)$ (Fig.5). The driest vegetal classes (5) covered a larger proportion of the meadows available for mowing in June (47\%) than in July (23\%). Logically, we observed the reverse pattern for the wettest vegetal classes 1, 2 and 3 which represented a lower proportion of the meadows mown in June (31\%) than in July (55\%). The proportion of the area covered by vegetation class 4 was constant between both periods (22\%). Regarding mowing date, birds of all species settled more frequently in parcels available for mowing in July than expected by chance (Chi ${ }^{2}$ $=521.10, d f=4, p<0.001)$. In the study area only $22 \%$ of meadow area was mown in July whereas between $45 \%$ and $66 \%$ of birds settled in this parcels (Fig.5).

Figure 2: Maps extract of the study area representing with the wetness gradient as determined by Ellenberg moisture index and vegetation classes ( 1 the wettest and 5 the driest). Grassland areas were used as a mask prior to mapping. 


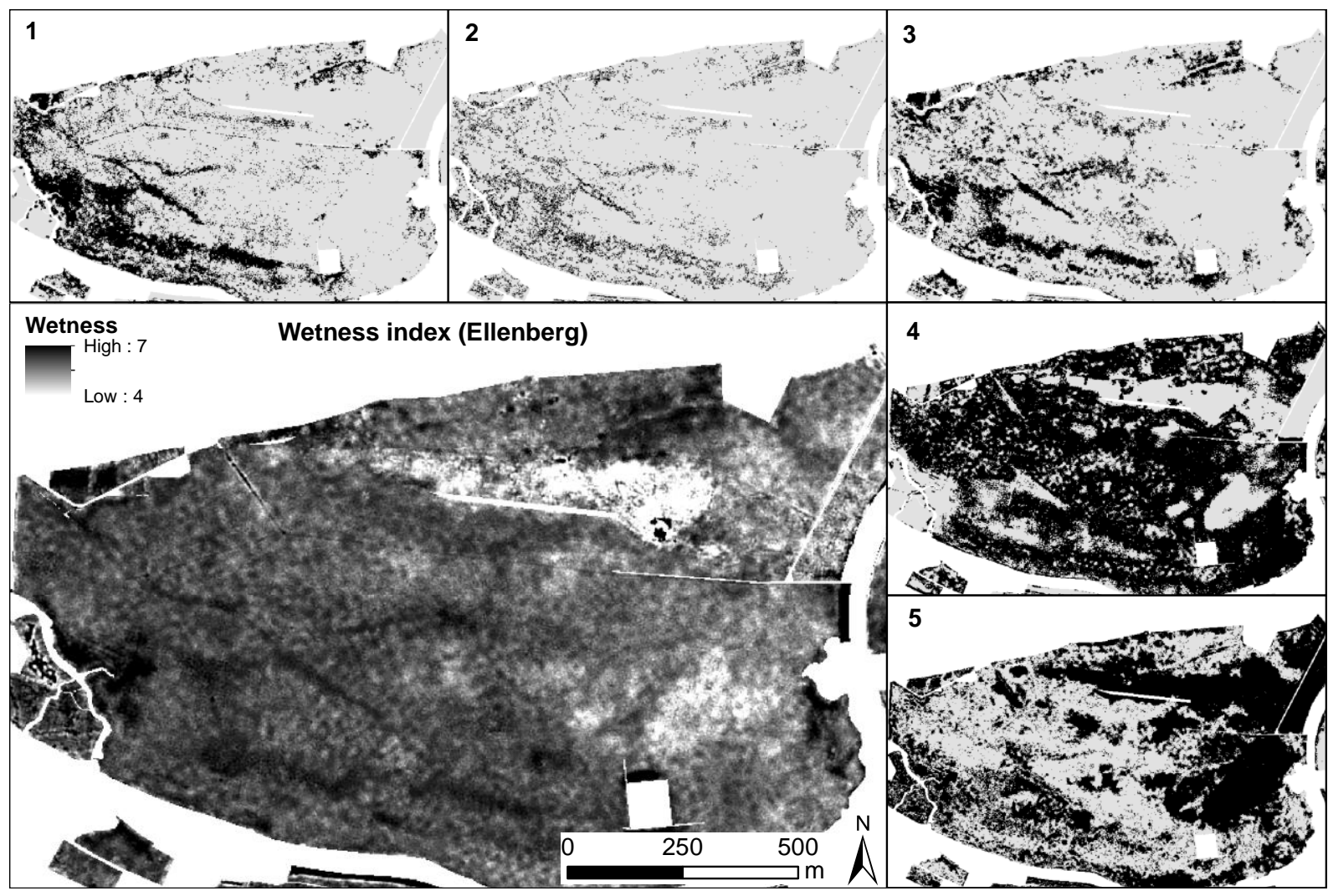

Figure 3: a. Linear relationship between Ellenberg moisture index and flood susceptibility index meadows $(n=44)$. 


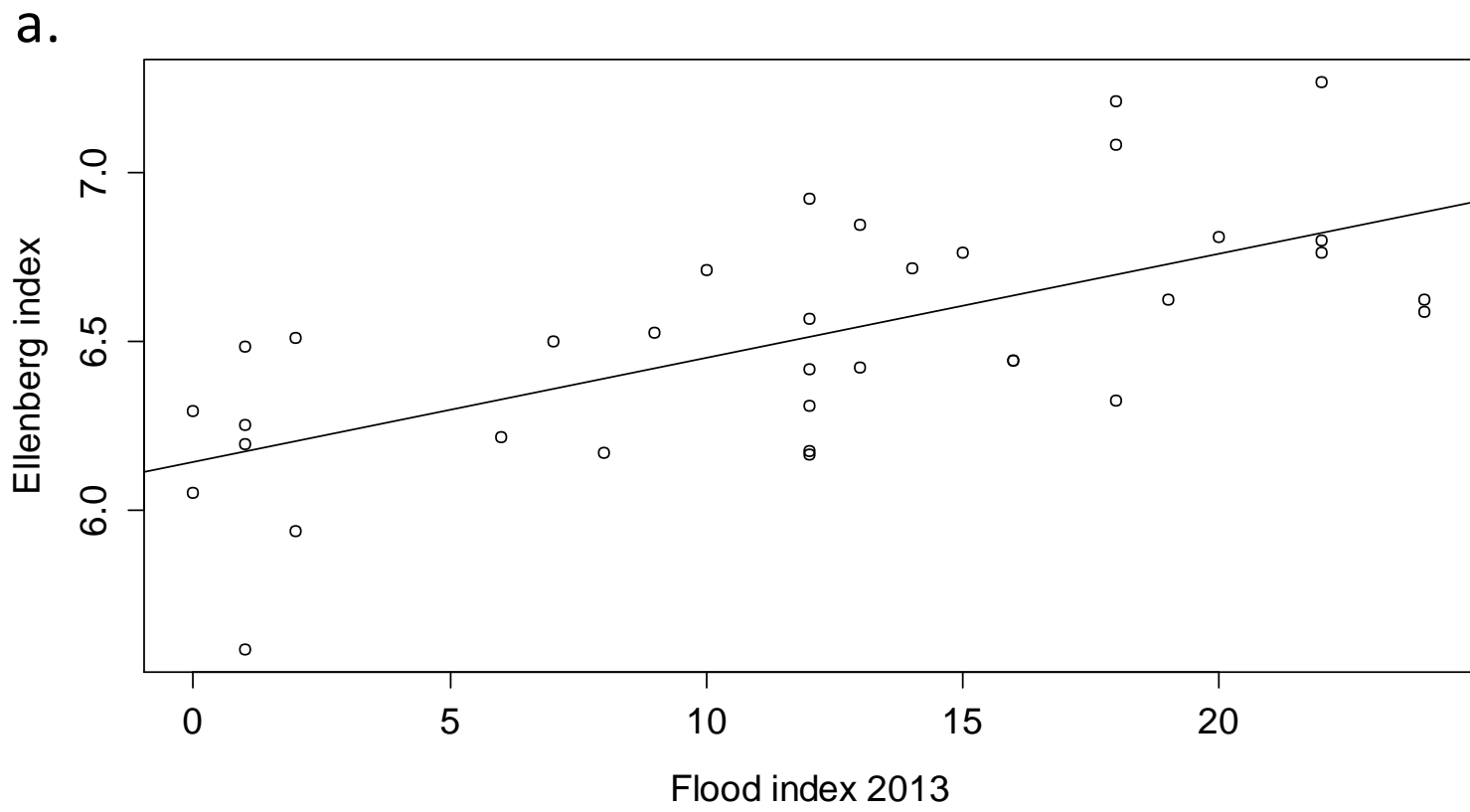

b.

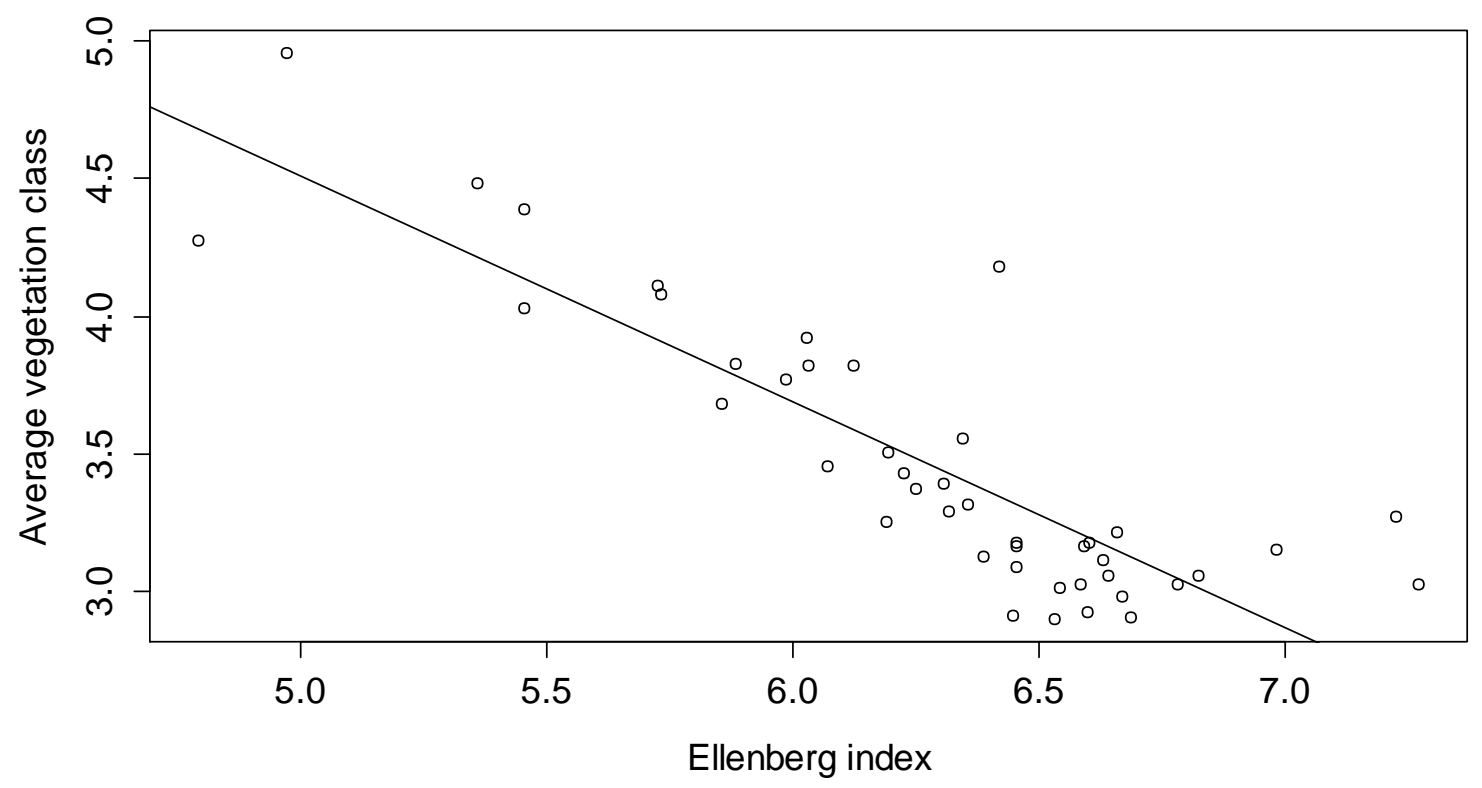

Figure 4: Boxplots of distribution of Ellenberg moisture index calculated for $100 \mathrm{~m}$ buffers around

311 species occurrences and in the study area (available). ${ }^{*}$ indicates that a species did not settle at

312 random across the wetness gradient and significantly preferred wetter meadows (Wilcoxon signed-

313 rank test). 


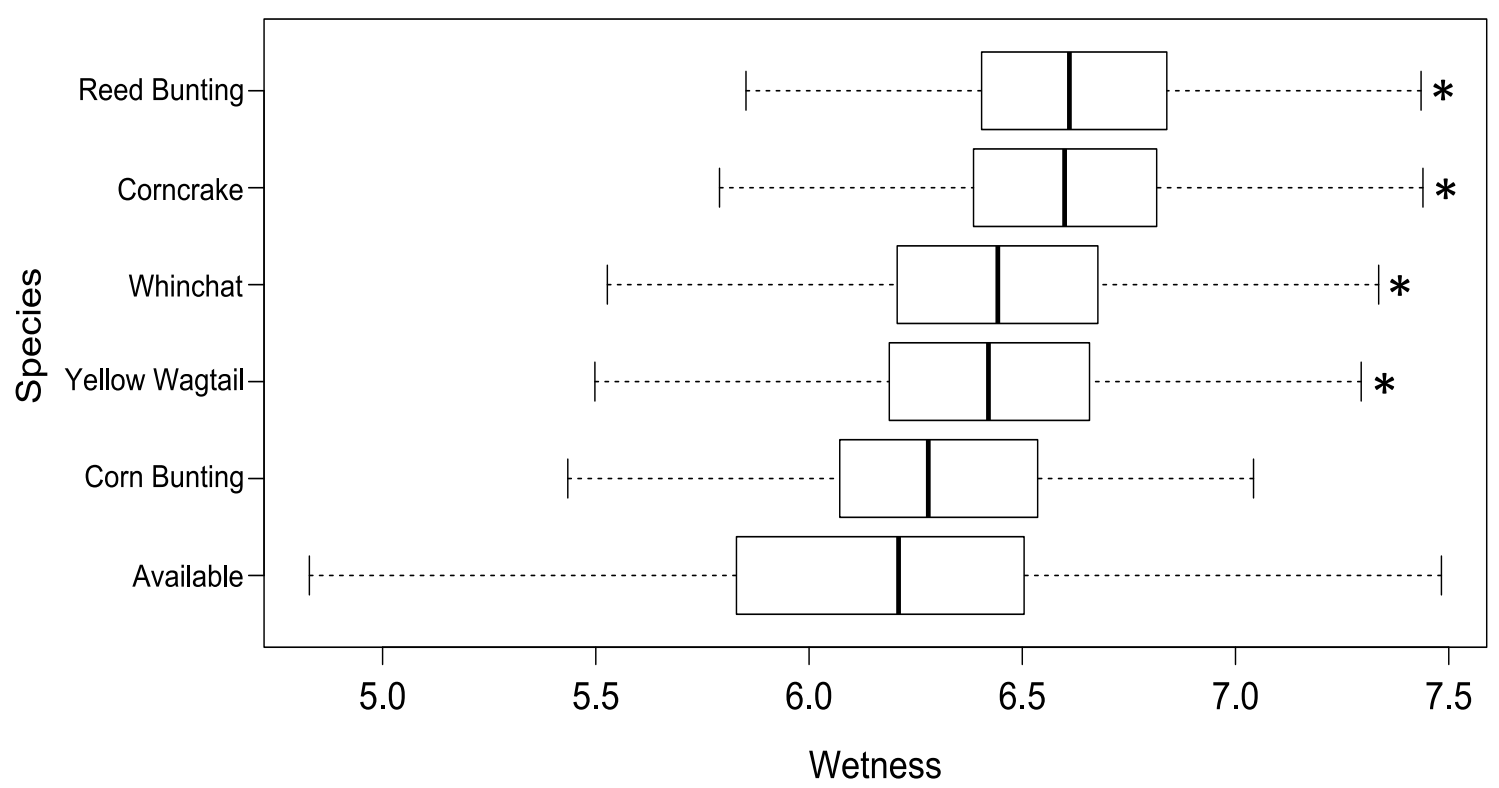

314

315

316 
Figure 5: Distribution of bird occurrences across vegetation classes in floodplain grasslands. The

318 first histogram represents the proportion of each class in the study area. All other histograms

319 represent the differences between the proportion of each vegetation class available in the study area

320 and the proportion of these classes in a $100 \mathrm{~m}$-buffer around bird occurrences. Filled symbols indicate

321 whether birds significantly selected or avoided this class (Wilcoxon signed-rank tests). Open symbols

322 indicate that no selection or avoidance was detected (see values in Table 2). Vegetation classes were

323 ranked from the wettest (1) to the driest (5).

Available

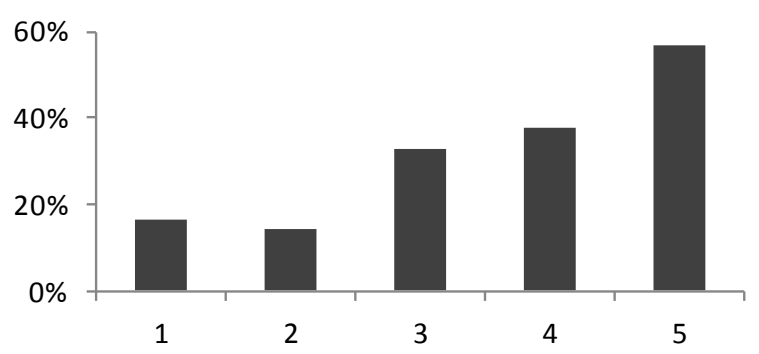

Yellow Wagtail

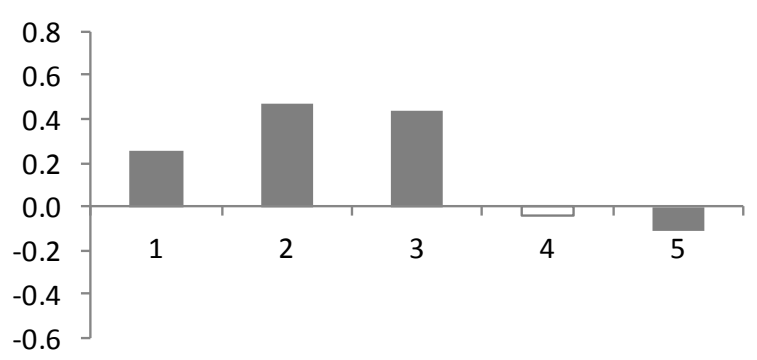

325
Reed Bunting

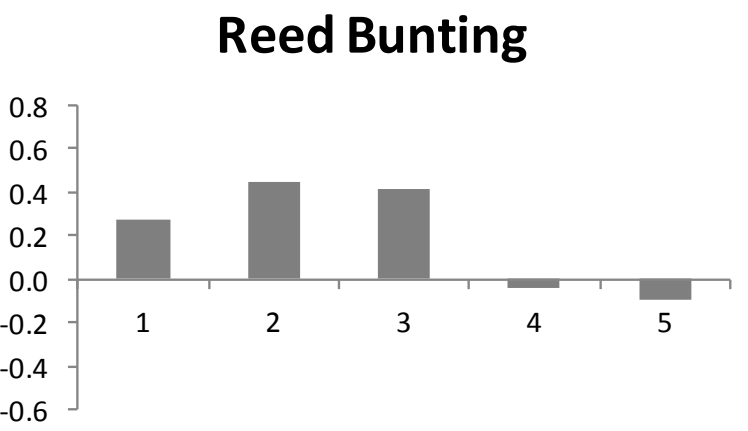

Whinchat

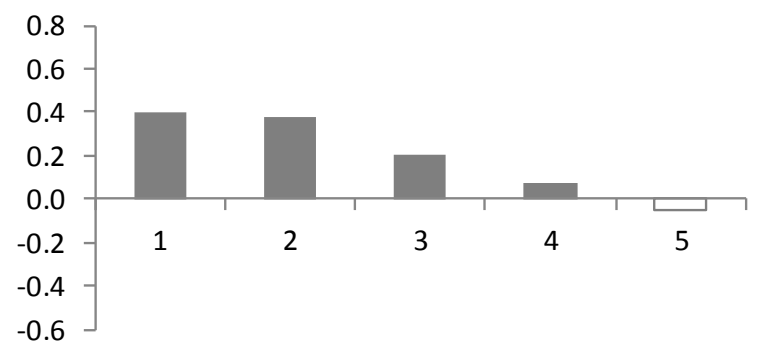

Corn Bunting

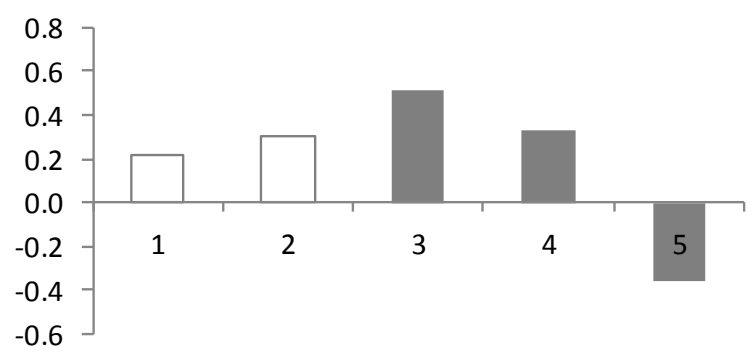

Corncrake

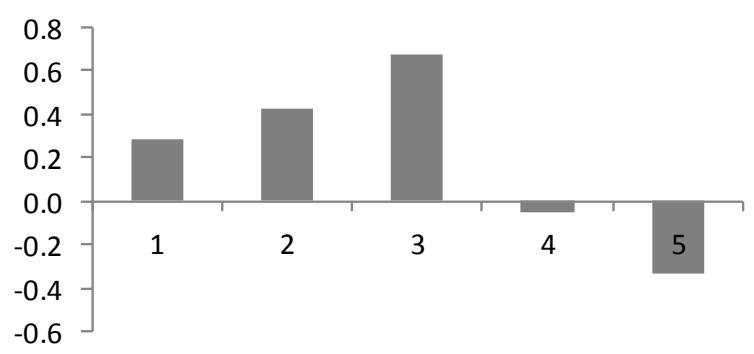


327 Figure 6: (left panel) Comparison between the distribution of the five vegetation classes (from $\mathrm{C}_{1}$

328 the wettest to $C_{5}$ the driest) observed across the grasslands of the study area and in the parcels

329 under AES contracts. Mowing dates were allowed either in June or in July. (right panel) Comparison

330 between the proportion of area available for mowing in June and July, and the proportion of the

331 population for each bird species on these two management options.
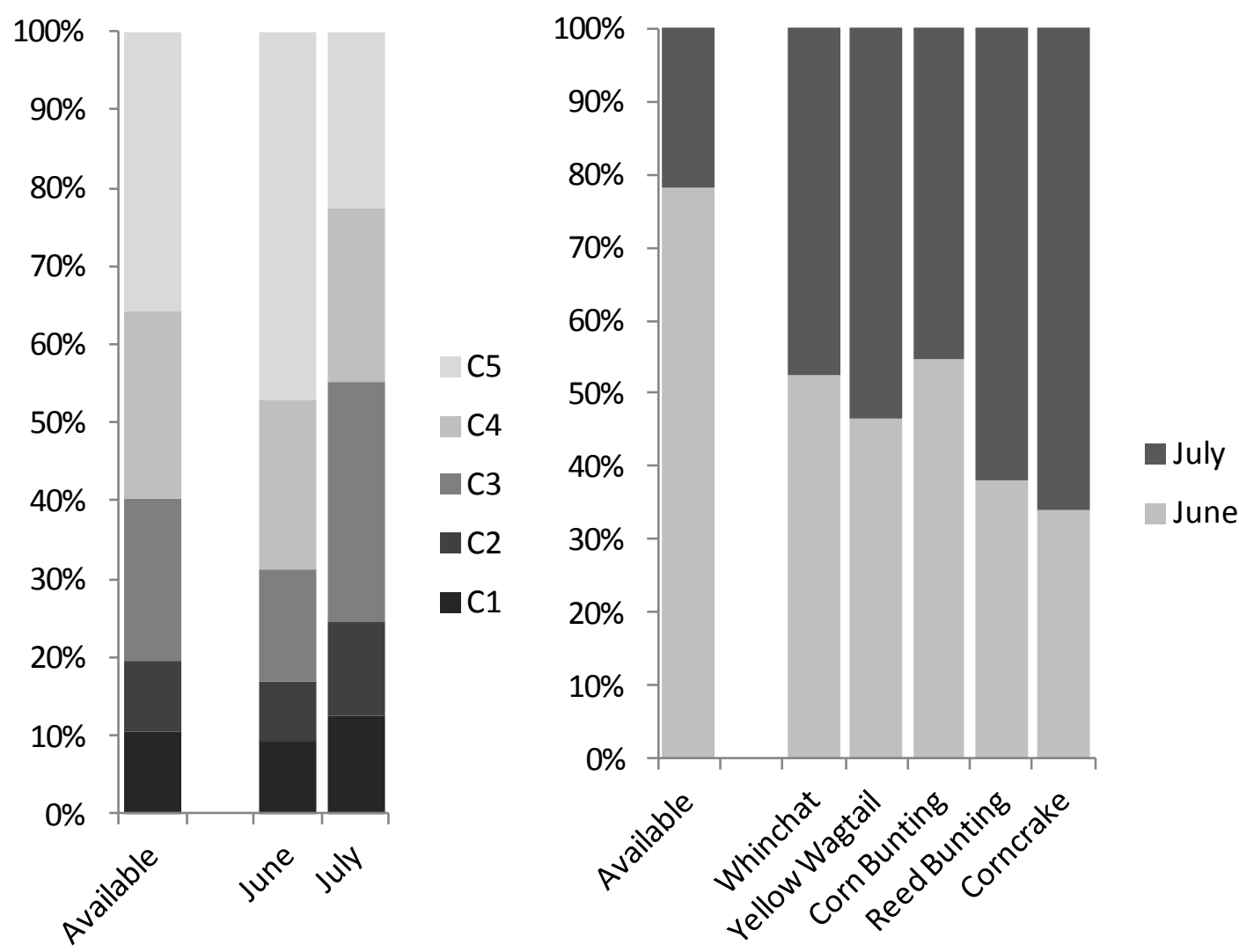
Table 2: Cover of each vegetation class within a 100m buffer around species occurrences and

344 random background locations. A species is considered to settle more often than by chance in a given

345 class when $p$-value $<0.05$ (value in bold). Vegetation classes were classified for the wettest (1) to the 346 driest (5). $V$ is the Wilcoxon statistic and $p$ is the corresponding $p$-value.
Table 2: Test of habitat selection comparing Ellenberg index in 100m buffers around bird occurrences and random background locations, and using bootstrap results of Wilcoxon tests. Selection is considered to occur when $p$-value $<0.05$, in this case the value is in bold.

\begin{tabular}{lccc} 
& p average & $2.50 \%$ & $97.50 \%$ \\
\hline Yellow Wagtail & $<0.001$ & $<0.001$ & $<0.01$ \\
Corn Bunting & 0.10 & $<0.001$ & 0.62 \\
Reed Bunting & $<0.001$ & $<0.001$ & $<0.001$ \\
Corncrake & $<0.001$ & $<0.001$ & $<0.001$ \\
Whinchat & $<0.001$ & $<0.001$ & $<0.001$ \\
\hline
\end{tabular}

\begin{tabular}{|c|c|c|c|c|c|c|c|c|c|c|}
\hline & \multicolumn{2}{|c|}{1} & \multicolumn{2}{|c|}{2} & \multicolumn{2}{|c|}{3} & \multicolumn{2}{|c|}{4} & \multicolumn{2}{|c|}{5} \\
\hline & $\mathrm{V}$ & $\mathrm{p}$ & $\mathrm{V}$ & $p$ & $\mathrm{~V}$ & $p$ & $\mathrm{~V}$ & $\mathrm{P}$ & $\mathrm{V}$ & $p$ \\
\hline & & & & & & $\mathbf{p}$ & & & & \\
\hline Whinchat & 62531 & $p<0.001$ & 72221 & $\mathrm{p}<0.001$ & 66832 & $<0.001$ & 57279 & $p<0.05$ & 46081 & 0.078 \\
\hline \multirow[t]{2}{*}{ Yellow Wagtail } & 6593 & 0.112 & 8265 & $p<0.001$ & 9339 & $\begin{array}{r}p \\
<0.001\end{array}$ & 5082 & 0.223 & 3786 & $p<0.001$ \\
\hline & & & & & & p & & & & \\
\hline Corn Bunting & 3279 & 0.998 & 3615 & 0.341 & 4744 & $<0.001$ & 4404 & $p<0.01$ & 1297 & $p<0.001$ \\
\hline \multirow[t]{2}{*}{ Reed Bunting } & 10291 & $p<0.001$ & 13992 & $p<0.001$ & 14941 & $\begin{array}{r}p \\
<0.001\end{array}$ & 6178 & $p<0.05$ & 3609 & $p<0.001$ \\
\hline & & & & & & p & & & & \\
\hline Corncrake & 68357 & $p<0.001$ & 94337 & $p<0.001$ & 108846 & $<0.001$ & 47725 & $p<0.01$ & 10081 & $p<0.001$ \\
\hline
\end{tabular}




\section{Discussion}

Floodplain grasslands, the location the work was conducted, do not represent a uniform habitat.

351

352

Soil moisture gradient generates spatial variation in the composition of plant community (Fig. 2).

Using remote sensing, we characterized Ellenberg index at the pixel scale $(2.5 \mathrm{~m})$ so that we could map the moisture gradient at a high spatial resolution. The ability of this index to represent wetness was confirmed by the positive relationship with flooding susceptibility, a variable that we could extract from direct observations in the field during a flood event (Fig 3a.). The vegetation community showed some discontinuity across the soil moisture gradient though using the TWINSPAN method (Hill, 1979) we could define five phytosociological classes spread across the soil moisture range. Average level of association in a plot was strongly related to Ellenberg wetness index (Fig 3b.). These remote sensing data provided us with a layer of an informative predictor, the moisture gradient, to analyse fine habitat selection of birds.

Basing on these data, we found that no bird species settled randomly across the grasslands of the study area. They rather selected parcels depending on vegetation composition, which itself reflected the moisture gradient. The wettest meadows (high values of Ellenberg index) hosted generally more grassland birds in 2011 (Fig. 4), a distribution pattern observed in other years (Noël, 2003, A. Besnard unpublished data). Even the Corn Bunting, which exploits a large range of open habitats (Donald and Evans, 1995) showed a tendency to select the wettest meadows. Consistently, birds did not settle randomly according to vegetation class. This approach provided additional information to the wetness index. The Reed Bunting and the Corncrake, specialists of grasslands and wetlands with tall sward (Brickle and Peach, 2004; Green et al., 1997a), settled in areas containing a higher proportion of the wettest vegetation classes (1-3) than available across the floodplain (Fig. 3b). They also avoided plots with a high proportion of the driest classes (4-5). Similarly, the Whinchat which is a 
specialist of extensively managed hay meadows (Müller et al., 2005), and the Yellow Wagtail which can breed in alternative habitats like crops (Gilroy et al., 2011) preferentially selected the wettest meadows. Finally, the Corn Bunting selected grasslands with a higher proportion of classes 3 and 4, and avoided both wettest and driest classes. Overall, no species selected areas covered by a large proportion of the driest class (5), confirming the results obtained by the method based on Ellenberg index. Interestingly, this latter class is the most represented in the study area (36\%) whereas classes 1, 2 and 3 cover respectively only 10\%, 9\% and 21\%. Species' responses to class 4 were more diverse. The Corn Bunting settled in areas offering a large cover of this class, and the Whinchat tended to slightly show the same pattern. In contrast, the Reed Bunting and the Corncrake tended to avoid areas where this type of vegetation was more abundant than observed in average in the study area. These results highlight interspecific differences in habitat selection and are consistent with the ecology of these birds. Yet, differences were usually described for a larger range of ecological conditions (Jacobs et al., 2012). It is thus particularly interesting to observe that it is possible to determine species-specific habitat selection profiles within a much narrower ecological range. Furthermore, species tended to keep their relative position in the wetness gradient with the restricted ecological range of conditions encountered within the grasslands of these floodplains.

Our results suggest that the wettest grasslands (high Ellenberg index and large proportion of classes 1-3) were the most suitable for birds. Intermediate class (4) were suitable for some species and avoided by others but selection or avoidance was lower. In contrast, the driest grasslands (class 5) tended to be avoided by all species. We can draw hypotheses to explain this pattern. The wettest classes can be characterized by a higher forb cover than drier class. We expect trophic resources (e.g. pollinator insects) (Oppermann, 1990; Pywell et al., 2011) and vegetation structure to depend on the grass/forbs ratio (Oppermann, 1990). All bird species are mainly insectivorous during the breeding season (Brickle, 1999; Brickle and Peach, 2004; Britschgi et al., 2006; Davies, 1977; Green et al., 
1997a). Therefore, the quantity or quality of trophic resources may be higher on the wet end of the moisture gradient than on its dry end. Vegetation structure may be of importance too as a higher proportion of forbs may provide better sites for building nest and more perches for foraging and social activities as well as reducing predation risk.

\section{Flood, meadow management and bird conservation}

Vegetation mapping based on remote sensing technique appears as a helpful tool to investigate habitat selection in grassland habitats and to guide conservation actions. In our study area, the proportion of any given vegetation class drastically differed between AES contract types (Fig. 5). Early mown parcels (June) were mostly covered by the driest vegetal classes whereas parcels mown later (July) were mostly covered by the wettest classes. This is a logical outcome of a scheme based on volunteering. Farmers tend to select the contract level which minimizes the loss of hay quality. On the driest meadows, that are mature early, farmers preferentially choose contracts with early mowing dates. It results that the spatial pattern of mowing dates matches fairly well the wetness gradient across the study area.

It is possible to describe the wetness gradient of an area using only topographical data (Besnard et al., 2013; Beven and Kirkby, 1979). However, the low altitudinal variation in floodplains may not be grasped by the resolution of available many digital elevation models, that are the raw data for computing topographic methods, which limit our ability to map accurately the wetness gradient. Also pixel size of these models may not be appropriate or relevant in species with small territories for which small-scale features of the habitat may matter, for their nest site for instance. In contrast, the high resolution provided by satellite imagery ( $2.5 \mathrm{~m}$ here) allows adjusting the spatial scale of the analysis to the scale relevant for any bird species. Digital elevation models can be available with very 
high altitudinal resolution in some areas, in which case it could be interesting to carry out a comparative assessment of these two methods. However, it is important to outline that unlike topographical methods the local plant community is an integrative measure of various processes generating soil moisture (topography, soil composition and climate). Vegetation mapping takes also into account anthropogenic modifications (like dams or drainages) which cannot be integrated by topographic methods, for instance in cultivated lands where vegetation depends mainly on agricultural processes. Finally, the remote sensing method is more ecologically realistic in naturally sown grasslands where environmental factors, namely flood, largely influence vegetation. This approach requires more resources for image acquisition, fieldwork, and botanical expertise than topographical approaches. However, these constraints are balanced by deeper insight into habitat selection of species, even in homogeneous landscapes, and probably the providing of more robust information to base on to delineate areas for conservation.

\section{Acknowledgement}

The study was funded by Plan Loire Grandeur Nature, European Regional Development Fund (ERDF), Région des Pays de la Loire and Agence de l'eau Loire-Bretagne. We are grateful to the LPO Anjou for providing us Corncrake data. This project is part of Zone Atelier Loire. The Spot 5 imagery was acquired thanks to the ISIS program. We also thank Xavier Solé and Antoine Body for their help in the field. 
Barton, K., 2013. MuMIn: Multi-model inference, R package version 1.9.13.

Anderson, M., 2001. A new method for non-parametric multivariate analysis of variance. Austral Ecol. 32-46.

Azpiroz, A.B., Isacch, J.P., Dias, R. a., Di Giacomo, A.S., Fontana, C.S., Palarea, C.M., 2012. Ecology and conservation of grassland birds in southeastern South America: A review. J. F. Ornithol. 83, 217246. doi:10.1111/j.1557-9263.2012.00372.x

Besnard, A.G., Jeunesse, I. La, Pays, O., Secondi, J., 2013. Topographic wetness index predicts the occurrence of bird species in floodplains. Divers. Distrib. 19, 955-963. doi:10.1111/ddi.12047

Besnard, A.G., Secondi, J., 2014. Hedgerows diminish the value of meadows for grassland birds: Potential conflicts for agri-environment schemes. Agric. Ecosyst. Environ. 189, 21-27. doi:10.1016/j.agee.2014.03.014

Beven, K., Kirkby, M.M.J., 1979. A physically based, variable contributing area model of basin hydrology/Un modèle à base physique de zone d'appel variable de l'hydrologie du bassin versant. Hydrol. Sci. J. 24, 43-69.

Biondi, E., 2011. Phytosociology today: Methodological and conceptual evolution. Plant Biosyst. - An Int. J. Deal. with all Asp. Plant Biol. 145, 19-29. doi:10.1080/11263504.2011.602748

Braun-Blanquet, J., 1964. Pflanzensoziologie: grundzüge der vegetationskunde.

Breiman, L., Friedman, J., Stone, C., Olshen, R., 1984. Classification and regression trees, Chapman \& . ed. New York.

Brennan, L., Kuvlesky, W., 2005. North American Grassland Birds: An Unfolding Conservation Crisis? J. Wildl. Manage. 69, 1-13. doi:10.2193/0022-541X(2005)069<0001:NAGBAU>2.0.CO;2

Brickle, N., 1999. Diet of nestling Corn Buntings Miliaria calandra in southern England examined by compositional analysis of faeces. Bird Study 46, 319-329.

Brickle, N.W., Peach, W.J., 2004. The breeding ecology of Reed Buntings Emberiza schoeniclus in farmland and wetland habitats in lowland England. Ibis (Lond. 1859). 146, 69-77.

Britschgi, A., Spaar, R., Arlettaz, R., 2006. Impact of grassland farming intensification on the breeding ecology of an indicator insectivorous passerine, the Whinchat Saxicola rubetra: Lessons for overall Alpine meadowland management. Biol. Conserv. 130, 193-205. doi:10.1016/j.biocon.2005.12.013

Broyer, J., 2007. Défintion d'un calendrier des fenaison compatible avec la reproduction des passereaux. Alauda 75, 145-158. 
Burnham, K. P., D. R. Anderson., 2002. Model selection and multimodel inference : a practical information-theoretic approach. Second edition. Springer, New York, New York, USA.

Chytrý, M., Otýpková, Z., 2003. Plot sizes used for phytosociological sampling of European vegetation. J. Veg. Sci. 563-570.

Corillon, R., 1981. Flore et végétation de la vallée de la Loire, Imprimerie. ed. Paris.

Davies, C.E., Moss, D., Hill, M.O., 2004. EUNIS habitat classification revised 2004.

Davies, N.B., 1977. Prey selection and social behaviour in wagtails. J. Anim. Ecol. 46, 37-57.

Davis, S., 2005. Nest-site selection patterns and the influence of vegetation on nest survival of mixedgrass prairie passerines. Condor 605-616.

Davis, S.K., Brittingham, M., 2004. Area sensitivity in grassland passerines: effects of patch size, patch shape, and vegetation structure on bird abundance and occurrence in southern Saskatchewan. Auk 121, 1130-1145.

Davranche, A., Lefebvre, G., Poulin, B., 2010. Wetland monitoring using classification trees and SPOT5 seasonal time series. Remote Sens. Environ. 114, 552-562. doi:10.1016/j.rse.2009.10.009

Davranche, A., Poulin, B., Lefebvre, G., 2013. Mapping flooding regimes in Camargue wetlands using seasonal multispectral data. Remote Sens. Environ. 138, 165-171. doi:10.1016/j.rse.2013.07.015

Donald, P., Evans, A., 1995. Habitat selection and population size of Corn Buntings Miliaria calandra breeding in Britain in 1993. Bird Study 42, 190-204.

Eggenberg, S., Möhl, A., 2013. Flora Vegetativa [Relié], 2th editio. ed. Bern.

Ejsmond, J., 2008. The effect of mowing on next-year predation of grassland bird nests: experimental study. Polish J. Ecol. 56, 299-307.

Ellenberg, H., Weber, H.E., Düll, R., Wirth, V., Werner, W., Paulißen, D., 1992. Zeigerwerte von Pflanzen in Mitteleuropa. Scr. Geobot 18, 1-258.

Esposito, F., Malerba, R.D., Semeraro, G., Tamma, V., 1999. The effects of pruning medods on the predictive accuracy of indices. Appl. Stoch. Model. Buisness Ind. 15, 277-299.

Fischer, K., Busch, R., Fahl, G., Kunz, M., Knopf, M., 2012. Habitat preferences and breeding success of Whinchats (Saxicola rubetra) in the Westerwald mountain range. J. Ornithol. 154, 339-349. doi:10.1007/s10336-012-0898-z

Fisher, R.J., Davis, S.K., 2010. From Wiens to Robel: A Review of Grassland-Bird Habitat Selection. J. Wildl. Manage. 74, 265-273. doi:10.2193/2009-020 
Foucault, B. De, 1984. Systémique,structuralisme et synsystématique des prairies hygrophiles des plaines atlantiques françaises. Univ. Rouen.

Gilroy, J.J., Anderson, G.Q. a., Vickery, J. a., Grice, P. V., Sutherland, W.J., 2011. Identifying mismatches between habitat selection and habitat quality in a ground-nesting farmland bird. Anim. Conserv. 14, no-no. doi:10.1111/j.1469-1795.2011.00480.x

Goward, S.N., Markham, B., Dye, D.G., Dulaney, W., Yang, J.L., 1991. Normalized Difference Vegetation Index Measurements From The Advanced Very High-Resolution Radiometer. Remote Sens. Environ. 35, 257-277.

Green, R., Rocamora, G., Schaffer, N., 1997a. Populations, ecology and threats to the Corncrake Crex crex in Europe. Vogelwelt 118, 117-134.

Green, R., Tyler, G., Stowe, T., Newton, A., 1997b. A simulation model of the effect of mowing of agricultural grassland on the breeding success of the corncrake (Crex crex). J. Zool. 243, 81-115.

Guo, X., 2004. Measuring Spatial and Vertical Heterogeneity of Grasslands Using Remote Sensing Techniques. J. Environ. Informatics 3, 24-32. doi:10.3808/jei.200400024

Helzer, C.J., Jelinski, D.E., 1999. The relative importance of patch area and perimeter-area ratio to grassland breeding birds. Ecol. Appl. 9, 1448-1458.

Hesselink, A., Weerts, H., Berendsen, H., 2003. Alluvial architecture of the human-influenced river Rhine, The Netherlands. Sediment. Geol.

Hill, M.O., 1979. TWINSPAN: A FORTRAN Program for Arranging Multivariate Data in an Ordered Two-way Table by Classification of the Individuals and Attributes.

Hill, M.O., Mountford, J.O., Roy, D.B., Bunce, R.G.H., 1999. Ellenberg's indicator values for British plants. ECOFACT Volume 2 Technical Annex.

Jacobs, R.B., Thompson, F.R., Koford, R.R., La Sorte, F. a., Woodward, H.D., Fitzgerald, J. a., 2012. Habitat and landscape effects on abundance of Missouri's grassland birds. J. Wildl. Manage. 76, 372-381. doi:10.1002/jwmg.264

Kleijn, D., Baquero, R. a, Clough, Y., Díaz, M., De Esteban, J., Fernández, F., Gabriel, D., Herzog, F., Holzschuh, a, Jöhl, R., Knop, E., Kruess, a, Marshall, E.J.P., Steffan-Dewenter, I., Tscharntke, T., Verhulst, J., West, T.M., Yela, J.L., 2006. Mixed biodiversity benefits of agri-environment schemes in five European countries. Ecol. Lett. 9, 243-54; discussion 254-7. doi:10.1111/j.14610248.2005.00869.x

Martinez, J., Letoan, T., 2007. Mapping of flood dynamics and spatial distribution of vegetation in the Amazon floodplain using multitemporal SAR data. Remote Sens. Environ. 108, 209-223. doi:10.1016/j.rse.2006.11.012

McNeely, J., 1994. Protected areas for the 21st century: working to provide benefits to society. Biodivers. Conserv. 405, 390-405. 
Moeslund, J., Arge, L., Bøcher, P., 2013. Topographically controlled soil moisture is the primary driver of local vegetation patterns across a lowland region. Ecosphere 4, 1-26.

Moilanen, A., Wilson, K., Possingham, H., 2009. Spatial conservation prioritization: quantitative methods and computational tools.

Morris, A.J., Gilroy, J.J., 2008. Close to the edge: predation risks for two declining farmland passerines. Ibis (Lond. 1859). 150, 168-177.

Müller, M., Spaar, R., Schifferli, L., Jenni, L., 2005. Effects of changes in farming of subalpine meadows on a grassland bird, the whinchat (Saxicola rubetra). J. Ornithol. 146, 14-23. doi:10.1007/s10336-004-0059-0

Noël, F., 2003. Étude de l'avifaune nicheuse des prairies inondables de fauche dans les Basses Vallées Angevines. Crex 7, 53-58.

Oppermann, R., 1990. Suitability of different vegetation structure types as habitat for the whinchat (Saxicola rubetra). Vegetatio 109-116.

Poulin, B., Davranche, A., Lefebvre, G., 2010. Ecological assessment of Phragmites australis wetlands using multi-season SPOT-5 scenes. Remote Sens. Environ. 114, 1602-1609. doi:10.1016/j.rse.2010.02.014

Price, E., 2002. Lowland Grassland and Heathland Habitats (Habitat Guides). Routledge.

Pywell, R.F., Meek, W.R., Hulmes, L., Hulmes, S., James, K.L., Nowakowski, M., Carvell, C., 2011. Management to enhance pollen and nectar resources for bumblebees and butterflies within intensively farmed landscapes. J. Insect Conserv. 15, 853-864. doi:10.1007/s10841-011-9383-x

Schaffers, A., Raemakers, I., Sýkora, K., Braak, C. Ter, 2008. Arthropod assemblages are best predicted by plant species composition. Ecology 89, 782-794.

Schaffers, A., Sýkora, K., 2000. Reliability of Ellenberg indicator values for moisture, nitrogen and soil reaction: a comparison with field measurements. J. Veg. Sci. 11, 225-244.

Suzuki, R., Xu, J., Motoya, K., 2006. Global analyses of satellite-derived vegetation index related to climatological wetness and warmth. Int. J. Climatol. 26, 425-438. doi:10.1002/joc.1256

Therneau, T.M., Atkinson, E.J., 1997. An Introduction to Recursive Partitioning Using the RPART Routines.

Tichý, L., 2002. JUICE, software for vegetation classification. J. Veg. Sci. 451-453.

Tryjanowski, P., Hartel, T., Báldi, A., Szymański, P., Tobolka, M., Herzon, I., Goławski, A., Konvička, M., Hromada, M., Jerzak, L., Kujawa, K., Lenda, M., Orłowski, G., Panek, M., Skórka, P., Sparks, T.H., Tworek, S., \& A.W., Żmihorski, M., 2011. Conservation of Farmland Birds Faces Different Challenges in Western and Central-Eastern Europe. Acta Ornithol. doi:10.3161/000164511X589857 
571 Tucker, M., Heath, M.F., Tomialojc, L., Grimmett, R., 1994. Birds in Europe: Their Conservation Status $572 \quad$ (Birdlife Conservation). BirdLife International.

573 Whittingam, M.J., Evans, K.L., 2004. The effects of habitat structure on predation risk of birds in 574 agricultural landscapes. Ibis (Lond. 1859). 146, 210-220.

575 
Table S1. Model selection for mapping the ewetness index using the MuMin R package. Only models with $\Delta$ AICC $<1.5$ are shown.

Coefficient estimates

Intercept

Df logLik AICC $\triangle$ AICC Weight

\begin{tabular}{|c|c|c|c|c|c|c|c|c|c|c|c|c|c|c|c|c|c|c|c|c|c|}
\hline & 1 & 2 & 3 & 4 & 5 & 6 & 7 & 8 & 9 & 10 & 11 & 12 & $\begin{array}{ll}13 & 14\end{array}$ & 15 & 16 & 18 & & & & & \\
\hline 114.10 & 0.19 & & & 49.73 & & & 1.65 & -164.96 & & & & & & -0.65 & & & 7 & -110.97 & 237.08 & 0.00 & 0.00048 \\
\hline 115.33 & & & & 49.95 & & 0.19 & 1.48 & -167.03 & & & & & & -0.66 & & & 7 & -111.02 & 237.18 & 0.10 & 0.00046 \\
\hline 105.32 & & & & 42.22 & & & 1.36 & -155.15 & & 0.17 & & & & -0.59 & & & 7 & -111.13 & 237.40 & 0.32 & 0.00041 \\
\hline 107.07 & & 0.17 & & 44.44 & & & 1.55 & -156.43 & & & & & & -0.55 & & & 7 & -111.17 & 237.47 & 0.39 & 0.00040 \\
\hline 84.54 & & -1.12 & & 25.56 & & & & -131.68 & & 1.25 & & & & -0.77 & & & 7 & -111.36 & 237.85 & 0.77 & 0.00033 \\
\hline 60.41 & 3.29 & -6.90 & & & & & & -109.44 & & 3.71 & & -2.71 & & -1.48 & & & 8 & -110.40 & 238.27 & 1.19 & 0.00027 \\
\hline 78.70 & & -1.57 & & & & 1.67 & & -159.23 & & & 45.54 & & & -0.93 & & & 7 & -111.67 & 238.48 & 1.40 & 0.00024 \\
\hline-19.01 & 5.30 & -8.37 & & & & & & & & 2.98 & & -2.36 & & -1.57 & 3.85 & & 8 & -110.52 & 238.51 & 1.44 & 0.00023 \\
\hline 139.51 & 1.12 & -0.96 & -56.04 & & & & 1.70 & -185.53 & & & & & & -0.86 & & & 8 & -110.53 & 238.52 & 1.45 & 0.00023 \\
\hline 139.25 & 1.11 & -0.95 & & & & & 1.70 & -185.38 & -37.46 & & & & & -0.86 & & & 8 & -110.53 & 238.53 & 1.45 & 0.00023 \\
\hline 139.19 & 1.11 & -0.95 & & & -56.21 & & 1.70 & -185.35 & & & & & & -0.86 & & & 8 & -110.53 & 238.53 & 1.45 & 0.00023 \\
\hline 100.51 & 0.10 & & & & -32.83 & & 1.29 & -142.17 & & & & & & -0.43 & & & 7 & -111.71 & 238.54 & 1.47 & 0.00023 \\
\hline 100.49 & 0.10 & & & & & & 1.29 & -142.13 & -21.86 & & & & & -0.43 & & & 7 & -111.71 & 238.55 & 1.47 & 0.00023 \\
\hline
\end{tabular}


580

581

582

583

584

585

586

587

588

589

590

591

592

593

594

595

596

597

598

599

Richardson, A. J., \& Everitt, J. H. (1992). Using spectra vegetation indices to estimate rangeland productivity. Geocarto International, 1, 63-69.

Adell, C., \& Puech, C. (2003). L'analyse spatiale des plans d'eau extraits par télédétection satellitale permet-elle de retrouver la marque cynégétique en Camargue? Bulletin de la société francaise de photogrammétrie et de télédétection,172, 76-86.

Rouse, J. W., Haas, R. H., Schell, J. A., \& Deering, D. W. (1973). Monitoring vegetation systems in the great plains with ERTS. Third ERTS Symposium, NASA SP-351,1.

Rondeaux, G., Steven, \& M, Baret, F. (1996). Optimization of Soil-Adjusted Vegetation Indices. Remote Sensing of Environment, 55, 95-107.

McFeeters, S. K. (1996). The use of the normalised difference water index (NDWI) in the delineation of open water features. International Journal of Remote Sensing, 17, 1425-1432.

Symonds, MRE., \& Moussalli, A., (2011). A brief guide to model selection, multimodel inference and model averaging in behavioural ecology using Akaike's Information Criterion, Behavioral Ecology and Sociobiology, 65, 13-21.

Huete, A. R. (1988). A Soil-Adjusted Vegetation Index (SAVI). Remote sensing of Environment, 25, 295-309.

Pearson, R.L., \& Miller, L.D. (1972). Remote mapping of standing crop biomass for estimation of the productivity of the short-grass Prairie, Pawnee National Grasslands, Colorado. Processing of the 8th International Symposium on Remote Sensing of Environment, ERIM, Ann Arbor, MI, 13571381. 
601 Wiley and Sons, New York, 721 p.

602 Caillaud, L., Guillaumont, B., \& Manaud, F. (1991). Essai de discrimination des modes d'utilisation 603 des marais maritimes par analyse multitemporelle d'images SPOT. Application aux marais maritimes $604 d u$ Centre Ouest. IFREMER report (H4.21) 485, 24 p. 